INTERNATIONAL JOURNAL OF RESEARCHES IN BIOSCIENCES, AGRICULTURE AND TECHNOLOGY

(C) VISHWASHANTI MULTIPURPOSE SOCIETY (Global Peace Multipurpose Society) R. No. MH-659/13(N)

www.vmsindia.org

\title{
FISH DIVERSITY OF LOHAHA LAKE, LOHARA DIST- CHANDRAPUR MAHARASHTRA, INDIA
}

\author{
P.M. Telkhade ${ }^{1}$ and S. H. Jambhule ${ }^{2}$ \\ ${ }^{1}$ Arts, Commerce and Science College Tukum, Chandrapur \\ ${ }^{2}$ Guru Nanak College Ballarpur, Dist. Chandrapur \\ ptelkhade@yahoo.in
}

\begin{abstract}
Fish is a valuable source of protein and occupied a significant position in the socio-economical fabric of South Asian countries. India has rich biological heritage that qualifies it, as one of the twelve-mega diversity nations of the world. The fishes alone contributing 2,546 species and the fishes of inland water bodies of Indian subcontinent have been subject of study since last century. The lack of information on the ichthyofauna is a big handicap for popularizing little known fish variety in a particular ecosystem. Thus there is need to survey fish fauna associated with different fresh water habitats, which will help in planning methods for their production and effective exploitation. The present study is carried out to study diversity of fishes in Lohara lake during 2012-13. This lake is $1 \mathrm{~km}$ away from the Lohara village, District Chandrapur. In the present investigation, 30 species of fishes belonging to 5 orders and 10 families were observed.
\end{abstract}

Keywords: lake, Water, Ichthyofauna

\section{Introduction:}

Biodiversity is essential for stabilization of ecosystem and protection of overall environmental quality. Fishes are rich source of food and nutrition and became an important and delicious food of man. Fish is a valuable source of protein and occupied a significant position in the socio-economical fabric of South Asian countries. India has rich biological heritage that qualifies it, as one of the twelvemega diversity nations of the world. The fishes alone contributing 2,546 species and the fishes of inland water bodies of Indian subcontinent have been subject of study since last century. The lack of information on the ichthyofauna is a big handicap for popularizing little known fish variety in a particular ecosystem. Thus there is need to survey fish fauna associated with different fresh water habitats, which will help in planning methods for their production and effective exploitation. (Sharma and Nayak, 2001). In India potential of fish culture is yet to be fully exploited. Fish biodiversity of reservoir is essentially represents the fish faunal diversity and their abundance. Lake conserves a rich variety of fish species which supports to the commercial fisheries. The fresh water sources like tanks, dams, and lakes contains about 20,000 fish species in world and 2179 species in India. Various workers have studied fishes of India like Day (1978), Khanna (1992), Suresh (2003), Jayaram (1994) and Price (1978)

The present investigation was undertaken to study fish diversity in Lohara lake, Lohara. The objective of the study was to assess the fish diversity of the area.

\section{Materials and Methods:}

The Lohara Lake is one $\mathrm{Km}$ away from the lohara village. The present study is carried out to study diversity of fishes in Lohara lake during 2012-13. Fishes were collected personally and with the help of fishermen from the Lohara lake. The fishes were identified up to species by referring standard literature of Day (1875), Jayaram (1994), Menon (1999) and Talwar and Jhingran (1991).

\section{Observation and Result:}

In the present investigation, 30 species of fishes belonging to 5 different orders and 9 families were observed. Out of 5 orders the Cypriniformes was observed dominant with 20 different species followed by Ophiocephaliformes with 6 different species. Order Perciformes shows two different species while Clupeiformes and Anguliformes shows 1 species of fishes. Family wise distribution showed dominance of Cyprinidae with 16 species followed by Ophiocephalidae with 04, Bagridae with 03, Siluridae with 01, Cichlidae with 03, each 01 of each Notopteridae, Gobidae, and Mastacembelidae. Among the different species Labeo and Catla were observed dominant in Order Cypriniformes and least appearance of Ompok pabda.

\section{Discussion:}

According to Jhingran (1977) fishes of the fresh or inland water bodies of the Indian subcontinent have been a subject of study since last century. Studies on ichthyofaunal diversity from different fresh water bodies of India have been carried out during last few decades by researchers like Alikunhi et al., (1955).

In the present investigation, 30 species of fishes belonging to 5 orders and 10 families were observed. Out of 5 orders the Cypriniformes was observed to be dominant with 20 different species followed by Ophiocephaliformes with 6 
different species. Order Perciformes shows two different species while Clupeiformes and Anguliformes shows 1 species of fishes. Kadam and Gayakwad (2006) recorded 23 fish species belonging to 6 orders in Masooli reservoir district Parabhani, Maharashtra.

Kumar (1990) reported 51 ichthyofauna of 4 families in Govindsagar reservoir, Himachal Pradesh, out of which 12 fishes were commercially important. Devi (1997) reported ichthyofauna in Ibrahimbagh and Sathamraj reservoirs in Hyderabad. He also reported that cypriniformes fishes dominated in these reservoirs. Jain (1998) reported seven categories in Rajasthan state. Sukumaran and Rahman (1998) stated that majority of the reservoirs in Karnataka have a large population of predatory fishes. A total of 27 fish species belong to 6 families were recorded in Pong reservoir (Singh, 2001). Jain (1998) reported 53 species fish fauna and grouped them into seven categories in Rajasthan state.

According to Jhingran 1977, the species were varying considerably in shape, size and their life span. The Maximum size and the age are specific for every species. The growth of particular fish species is dependent on its environment. Sakhare and Joshi (2003) reported the ichthyofauna of Bori reservoir in Maharashtra. In present investigation five species of major carps Catla, Rohu, Marigal, Common carp and Grass carp are found most abundant, some species found abundant and some species each of less abundant and rarely found in the lake. All fishes useful as food fishes.

Table 1.1: Diversity of Ichtyofauna in Lohara lake during year 2012-13

\begin{tabular}{|l|l|l|l|}
\hline S.N. & Name of Fishes & Order & Family \\
\hline 1 & Labeo gonius & Cypriniformes & Cyprinidae \\
\hline 2 & Labeo calbasu & Cypriniformes & Cyprinidae \\
\hline 3 & Labeo rohita & Cypriniformes & Cyprinidae \\
\hline 4 & Catla catla & Cypriniformes & Cyprinidae \\
\hline 5 & Cyprinus carpio & Cypriniformes & Cyprinidae \\
\hline 6 & Cirrhinus mrigala & Cypriniformes & Cyprinidae \\
\hline 7 & Ctenopharyngodon idella & Cypriniformes & Cyprinidae \\
\hline 8 & Puntius sarana sarana & Cypriniformes & Cyprinidae \\
\hline 9 & Rasbora daniconius & Cypriniformes & Cyprinidae \\
\hline 10 & Puntius sophore & Cypriniformes & Cyprinidae \\
\hline 11 & Amblypharyngodon mola & Cypriniformes & Cyprinidae \\
\hline 12 & Puntius ticto & Cypriniformes & Cyprinidae \\
\hline 13 & Barilius bendelisis & Cypriniformes & Cyprinidae \\
\hline 14 & Wallago attu & Cypriniformes & Cyprinidae \\
\hline 15 & Punctius conchonius & Cypriniformes & Cyprinidae \\
\hline 16 & Lepidocephalichthys & Cypriniformes & Cyprinidae \\
\hline 17 & Chela bacaila & Cypriniformes & Siluridae \\
\hline 18 & Mystus seenghala & Cypriniformes & Bagridae \\
\hline 19 & Mystus cavisius & Cypriniformes & Bagridae \\
\hline 20 & Mistus vittatus & Cypriniformes & Bagridae \\
\hline 21 & Ophiocephalus punctatus & Ophiocephaliformes & Ophiocephalidae \\
\hline 22 & Ophiocephalus striatus & Ophiocephaliformes & Ophiocephalidae \\
\hline 23 & Ophiocephalus gachua & Ophiocephaliformes & Ophiocephalidae \\
\hline 24 & Ophiocephalus marulis & Ophiocephaliformes & Ophiocephalidae \\
\hline 25 & Chanda nama & Ophiocephaliformes & Cichlidae \\
\hline 26 & Chanda ranga & Ophiocephaliformes & Cichlidae \\
\hline 27 & Sorotherodon mossambicus & Perciformes & Cichlidae \\
\hline 28 & Mastecambalus armatus & Perciformes & Mastacembelidae \\
\hline 29 & Glassogobius giuris & Anguilliformes & Notopteridae \\
\hline 30 & Notopterus notopterus & Cluipeiformes & Gobidae \\
\hline
\end{tabular}

\section{References:}

Alikunhi, K.H., Chaudhary, H. and Ramchandran, V. (1955): On the mortality of crop try in the nursery ponds and role of plankton in the survival and growth, Indian. J. Fish 2: Pp. 257-313.

Day, F. (1875): The fishes of India, being a natural history of the fishes known to inhabit the seas and freshwaters of India, Burma and Ceylon., Test and atlas, 4 ports London.
Devi, B. S. (1997): Present status, Potentialities, Management and Economics of Fisheries of two minor Reservoir of Hyderabad. Ph.D. thesis, Osmania University

Jain, A.K. (1998): Fisheries resource management in Rajasthan. An overview of present status and future cope. Fishing Chimes, 17(11): 9-15. 
Jayaram, K.C. (1994): The freshwater fishes of India, A handbook, Zoological survey of India, Calcutta.

Jhingran, V.G. (1977): Fish and Fisheries of India., Hindustan Publications Corporation, India, New Delhi.

Kadam, S.U. and Gayakwad J.M. (2006): Ichthyofauna of Masooli reservoir, district Parbhani, Maharashtra- A study of inland reservoir fishery in India. J. Aqua. Biol., 21(2): 59-61.

Khanna, D. R. (1993): Ecology and Pollution of Ganga River., Ashish Publishing House, Delhi. $1-241$.

Kumar, K. (1990): Management and development of Gobindsagar reservoir. A case study. Proc. Nat. workshop reservoir Fish: 1320.

Menon, A.G.K. (1999): Checklist freshwater fishes of India. Z. S. I. Kolkata.

Price, D.R.H. (1978): Fish as Indicator of water quality. Paper presented at the international symposium on biological indicators of water quality in new castle. Proc. Indian Acad. Sci. (63):Pp. $57-66$

Sakhare, V.B. and Joshi P.K. (2003): Reservoir fishery potential of Parbhani district, Maharashtra. Fishing Chimes, 23(5): 13-16.

Sharma, S.V. and Nayak D.Y. (2001): Checklist of fishes inhabiting in water bodies in Nallamali hill range in Andhra Pradesh. J. Aqua. Biol. 16(1): 35-36.

Singh, G, (2001): Status of development of fisheries of Pong reservoir (Himachal Pradesh). Fishing Chimes, 21(1) 88-90.

Sukumaran, P.K and Rahman, M.F. (1998): Prospects of reservoir fisheries development in Karnataka. Fishing Chimes, 18 (8): 19-20.

Suresh, V.R. (2003): Status of Loktak lake fisheries and approach for their sustainable development. Fishing Chimes. 23(3): 40-44.

Talwar, P.K. and Jhingran A.G. (1991): Inland fishes of India and adjacent countries. Oxford and IBH Publishers, New Delhi. 